\title{
Full mouth rehabilitation for a Parkinson's diseases patient with chronic periodontitis: a case report
}

\author{
Eun-Sol Koh, Jong-Jin Kim', Jin Baik', Hyun-Suk Cha², Joo-Hee Lee ${ }^{2} *$ \\ 'Divison of Prosthodontics, Department of Dentistry, Asan Medical Center, Seoul, Republic of Korea \\ ${ }^{2}$ Divison of Prosthodontics, Department of Dentistry, Asan Medical Center, College of Medicine, University of Ulsan, Seoul, \\ Republic of Korea
}

Parkinson's disease is a neurological disorder characterized by tremor, bradykinesia, akinesia, postural instability, and muscular rigidity, which is caused by the depletion of neurotransmitters such as dopamine. Cooperative dental treatment is more challenging because of tremor of Parkinson's disease. In this case, a 47-year-old Parkinson's disease patient with chronic periodontitis was treated with full-mouth rehabilitation using conventional fixed prostheses and implant fixed partial denture, which attained satisfactory outcomes functionally and esthetically. Short term periodic follow-ups will be needed with consideration for the characteristics of Parkinson's disease such as decreased manual dexterity. (J Dent Rehabil Appl Sci 2019;35(4):228-34)

Key words: Parkinson's disease; implants; full mouth rehabilitation; chronic periodontitis

\begin{abstract}
서론
파킨슨병은 도파민과 노르에피네프린과 같은 신경전 달 물질이 고갈되어 생기는 신경변성 질환으로, 떨림, 느 려진 움직임, 근육의 경직, 자세 불안정성, 보행장애 등의 특징을 나타내고 40세 이상의 중년기와 노년기에 많이 발생한다. 파킨슨병 환자의 구강내 소견으로 저작 속도 와 혀의 움직임이 느려지고, 구각부에서 침을 흘리며, 약 물 복용으로 인해 미각이 변화하는 등의 현상이 관찰된 다. 파킨슨병 환자의 $24 \%$ 가 구강작열감증후군을 경험하 는데, 혀, 경구개, 구강저, 입술, 뺨 등에서 작열감이 보고 되고 있고 유치악 환자와 무치악 환자 모두에서 관찰되 며 의치의 착용 유무와도 상관이 없다. ${ }^{1,2}$

파킨슨병 환자는 근육 운동 조절이 어려워 섬세한 손 조작을 할 수 없을 뿐 아니라 우울감 및 인지적인 문제로

\footnotetext{
${ }^{*}$ Correspondence to: Joo-Hee Lee

Professor, Division of Prosthodontics, Department of Dentistry, Asan Medical Center, College of Medicine, University of Ulsan, 88 Olympic-ro 43-gil, Songpa-gu, Seoul, 05505, Republic of Korea

Tel: +82-2-3010-3850, Fax: +82-2-3010-6967, E-mail: ljhl11911@hanmail.net Received: August 14, 2019/Last Revision: August 16, 2019/Accepted: November 13,2019
}

인해 구강 위생 관리를 효과적으로 하기 힘들다. 구강 위 생 관리가 제대로 이루어지지 않아 치주 질환, 치아 우식 의 유병률이 높으며 그로 인해 조기에 치아를 상실할 위 험성이 크다. 또한 파킨슨병 환자들이 구각부에서 침을 흘리는 현상이 관찰되지만 실제적으로 생성되는 침의 양 은 같은 나이의 일반인과 비교시 더 적기 때문에 치아 우 식의 위험성은 더 높다. ${ }^{3}$

의치의 경우 구강 근육을 이용하여 환자가 의치를 조 절하는 능력이 중요한데 파킨슨병 환자는 구강건조증이 나 경직된 근육으로 인해 의치의 조작이 어렵고, 더불어 의치의 유지, 지지, 안정 또한 감소하게 된다. 이런 경우 전통적인 가철성 장치에 비해 오버덴처나 임플란트 지지 수복물은 파킨슨병 환자의 저작능력을 증가시키고 나아 가 전반적인 구강 건강의 질을 향상시킬 수 있다. ${ }^{1,4}$

본 증례에서는 파킨슨병을 않고 있는 만성 치주염 환

Copyright@ 2019 The Korean Academy of Stomatognathic Function and Occlusion. (c) It is identical to Creative Commons Non-Commercial License. 
자에게 임플란트 식립을 포함한 전악 고정성 보철 수복 을 시행하였고, 기능적, 심미적으로 만족할만한 결과를 얻을 수 있었다. 이후 1 년간의 관찰 기간 동안 안정적인 예후를 보였기에 이를 보고하고자 한다.

\section{증례보고}

본 증례의 환자는 47 세의 남자 환자로 만성 치주염과 하악 전치의 상실을 주소로 치과에 내원하였다. 2005년 부터 파킨슨병을 않고 있었고 이와 관련된 약물을 복용 하고 있었으며 치과적으로 특이할만한 병력은 없었다. 파킨슨병으로 인해 떨림 및 보행장애, 손 조작능력의 저 하 등이 관찰되었고, 침을 흘리거나 미각이 변화하는 것 과 같은 구강 내 증상은 관찰되지 않았다. 환자는 협조 적이고 치료에 대한 의지가 강하였으며 기능적인 회복을 원하고 있었다.

환자는 구강 위생이 좋지 않았고 전반적인 치석 침착 과 일부 깊은 치주낭이 관찰되었다. 구강 내 소견으로 하 악 중절치 2 개가 상실된 상태였고, 하악 측절치와 견치는
교합평면에서 상방으로 정출되어 있었다. 상악 중절치는 치근이 노출되었으며 열구를 통해 농이 배출되고 있었 다. 상악 구치부 보철물 하방에서는 이차 우식이 관찰되 었고, 하악 구치부에서는 교합평면이 설측으로 기울어진 부적절한 보철물이 관찰되었다(Fig. 1). 파노라마 방사선 사진에서는 상악 양측 구치부와 상하악 전치부의 국소적 인 치조골 소실 및 상악 좌측 중절치의 치근단 투과성 병 소를 관찰할 수 있었다(Fig. 2).

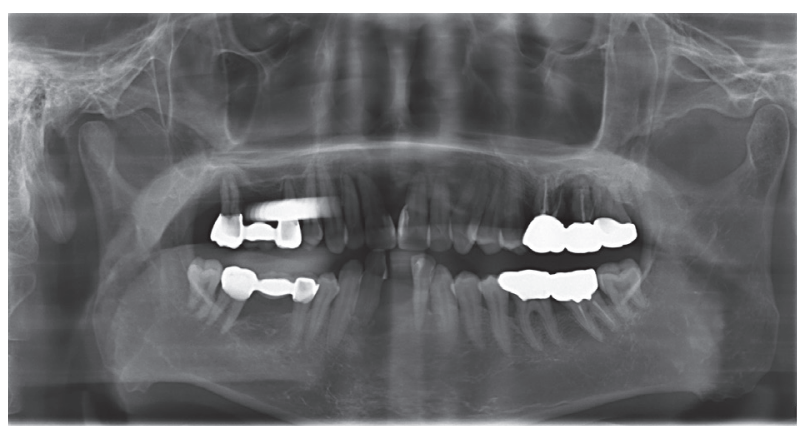

Fig. 2. Radiographic evaluation before treatment (Panoramic view).
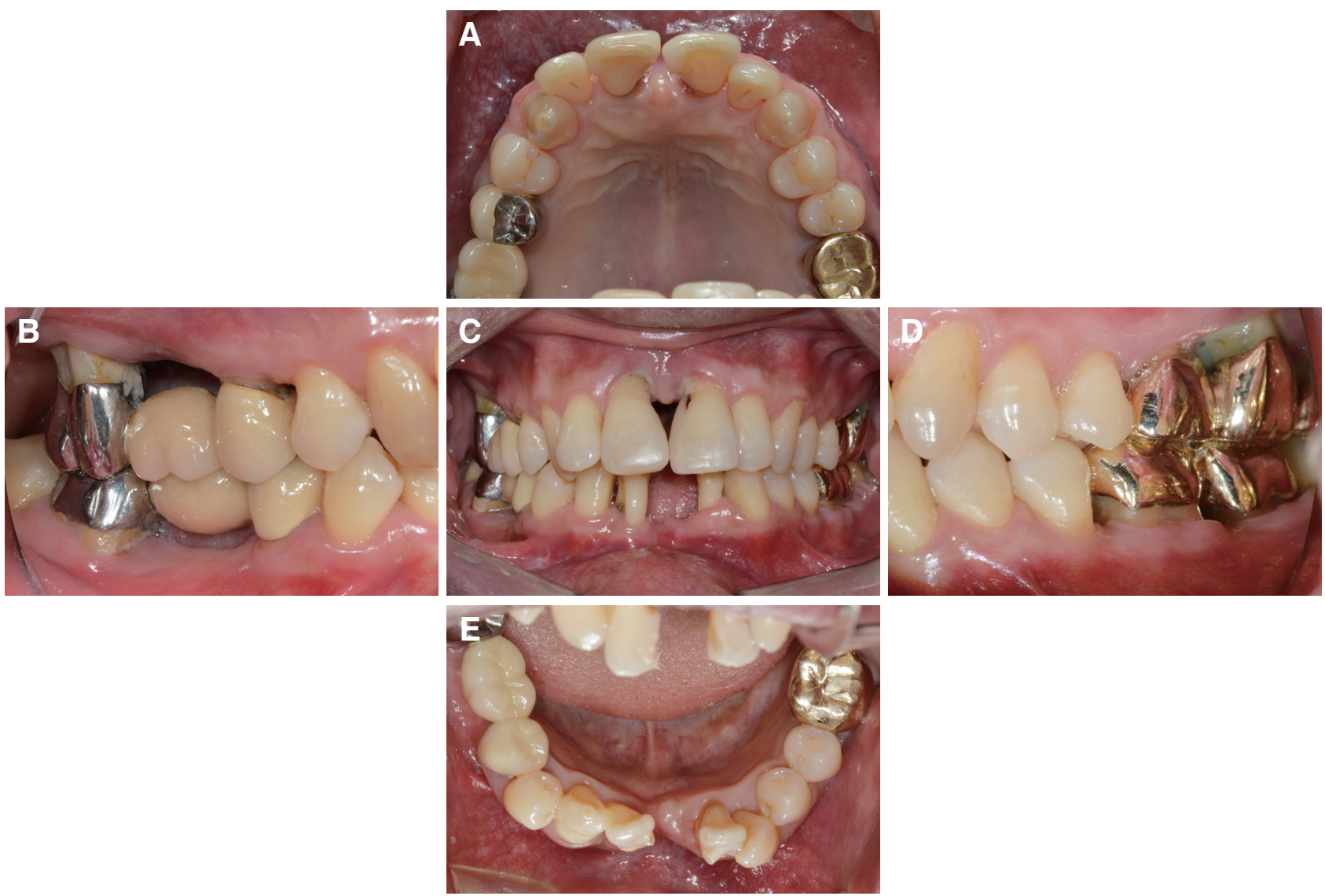

Fig. 1. Preoperative intraoral photographs. (A) Maxillary occlusal view, (B) Right lateral view, (C) Frontal view, (D) Left lateral view, (E) Mandibular occlusal view. 
모형 분석은 상하악 알지네이트 예비인상을 채득하여 진단모형을 제작한 뒤 반조절성 교합기 $(\mathrm{KaVO}$ PROTAR evo 5B articulator, KaVo Dental GmbH, Biberach, Germany)에 부착하여 시행하였다. 방사선학적 검사 결 과 상악 구치부의 심한 치조골 상실이 관찰되었으나 구 치부 지지는 안정적으로 유지되고 있었기에 수직교합고 경의 소실은 일어나지 않았다고 판단하였다. 그리고 치 주적으로 예후가 좋지 않은 일부 상악 전치 $(\# 12,11,21)$ 와 상악 구치(\#15,17,26,27), 그리고 잔존 제 3대구치 (\#28,38,48)를 발거하기로 하였다. 교합평면에 비해 과정 출되어 수복이 불가능한 하악 측절치도 같이 발거하기로 계획하였다.

치아상실 부위에 대해서는 환자의 나이 및 떨림, 손 조 작능력 저하 등을 고려하여 임플란트 식립을 포함한 고 정성 수복을 우선 순위로 두고 치료계획을 수립하였다. 상하악 전치부는 만성 치주염으로 인한 치조골 소실로 임플란트 식립 대신 브릿지를 이용한 고정성 보철 수복 을 하기로 하였다. 하악의 경우 과정출된 견치는 정출량 이 많아 교합평면에 맞춰 삭제시 치수의 노출 가능성이 매우 높고, 임상 치관의 길이가 짧아지기 때문에 의도적 근관 치료와 치관 확장술을 계획하였다. 하악 좌측 제 1 대구치의 금관과 우측의 3 단위 고정성 보철물은 교합평 면 수정을 위해 재제작을 하기로 하였고, 하악 우측 제 1 대구치 부위의 상실된 치아는 임플란트 수복으로 진행하 기로 하였다. 또한 상악 구치부에는 치조골 소실로 인해 골이식을 동반한 임플란트 식립을 계획하였다. 교합 양 식은 중심위와 최대교두 감합위에서 차이가 없도록 하였 고, 측방 운동시에는 견치 유도 교합을 부여할 수 있도록 하였다. 중심위로 하악을 유도하기 위해 양손유도조작법 을 사용하였다. 치료 계획에 맞추어 보철 전 처치 진행하 고, 진단 왁스업 시행하여(Fig. 3) 상하악에 임시 보철물
제작하였으며, 상악 구치부에는 임플란트 수복 전까지 사용할 임시 틀니 제작하였다.

상하악 구치부에 임플란트 식립 위해 수술용 가이드 제작하여 콘빔씨티(Cone Beam computed tomography, $\mathrm{CBCT}$ ) 촬영하였고, 잔존 골량 확인 및 임플란트 위치 에 대한 분석 시행하였다. 상악의 경우 최후방 부위 잔존 골이 부족하고 환자의 불수의적 운동으로 인해 접근성 이 떨어져 제 1 대구치까지 수복하기로 결정하였다. 잔존 골이 부족한 우측 상악 구치부(\#15,16)와 하악 구치부 (\#46)에는 골이식을 시행 후 4개월의 치유 기간 후에 일 회 접근법(1-stage)으로 외부 연결방식 임플란트(Osstem USII SA, Osstem, Seoul, Korea) 식립하였다. 상악 좌측 구치부(\#26)는 치조정 접근법(crestal approach)을 통해 골이식을 동반한 외부 연결방식 임플란트(Osstem USII SA, Osstem, Seoul, Korea) 식립을 시행하였다(Fig. 4). 3 - 4개월 간의 치유 기간 후 나사유지형(screw type)의 PMMA (polymethyl methacrylate) 레진 임시 보철물 제 작하였고 우측 하악 부위(\#46)는 기존 임시 수복물을 수 정한 뒤 임플란트 임시 보철물 장착하였다(Fig. 5). 임시 보철물을 사용하는 동안 심미성 및 저작능력, 구강위생

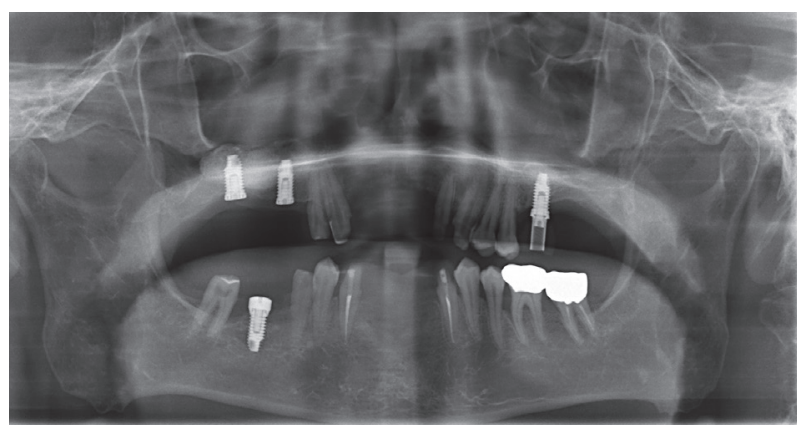

Fig. 4. Panoramic radiograph after implant installation.
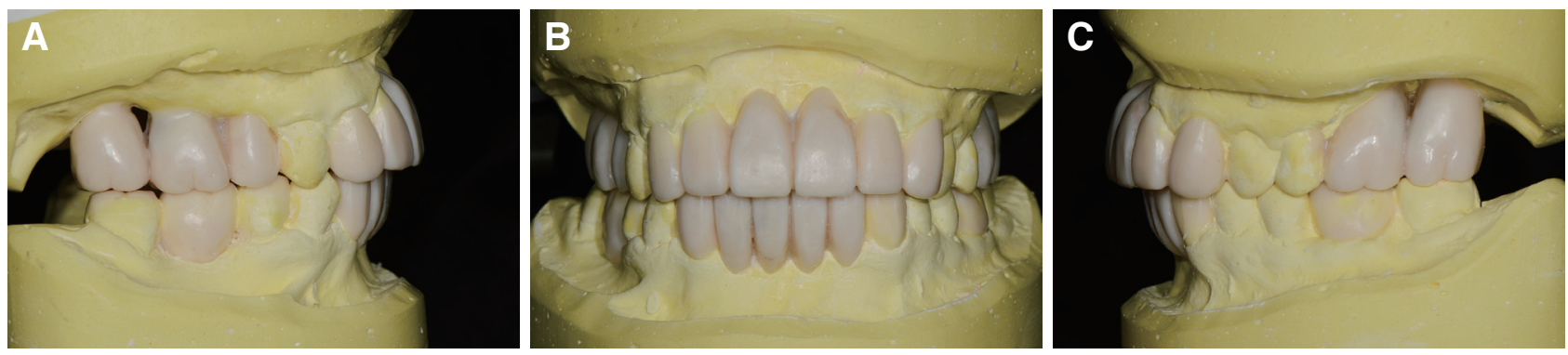

Fig. 3. Diagnostic wax-up. (A) Right lateral view, (B) Frontal view, (C) Left lateral view. 

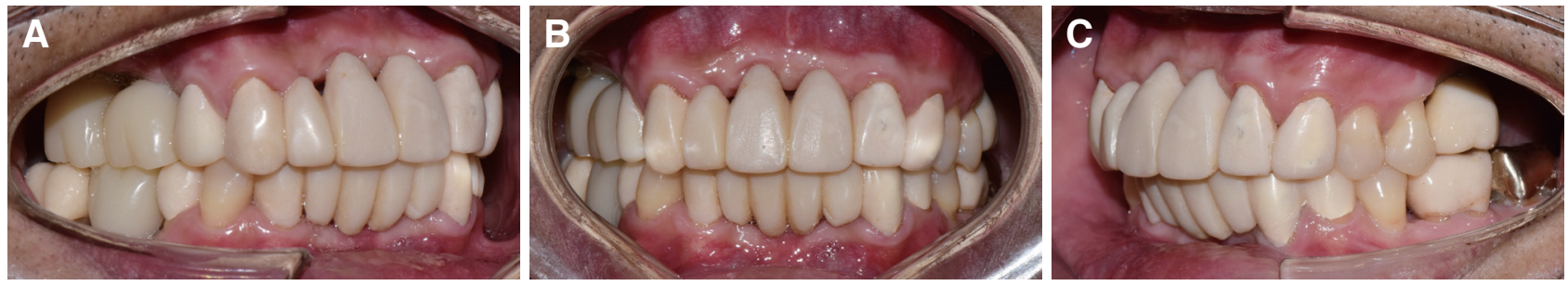

Fig. 5. Provisional restoration after implant installation. (A) Right lateral view, (B) Frontal view, (C) Left lateral view.
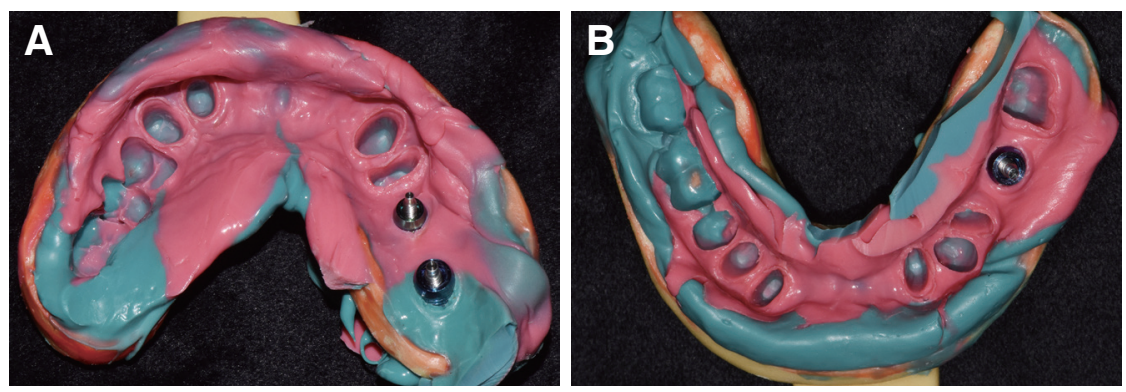

Fig. 6. Final impression taking. (A) Maxilla, (B) Mandible.
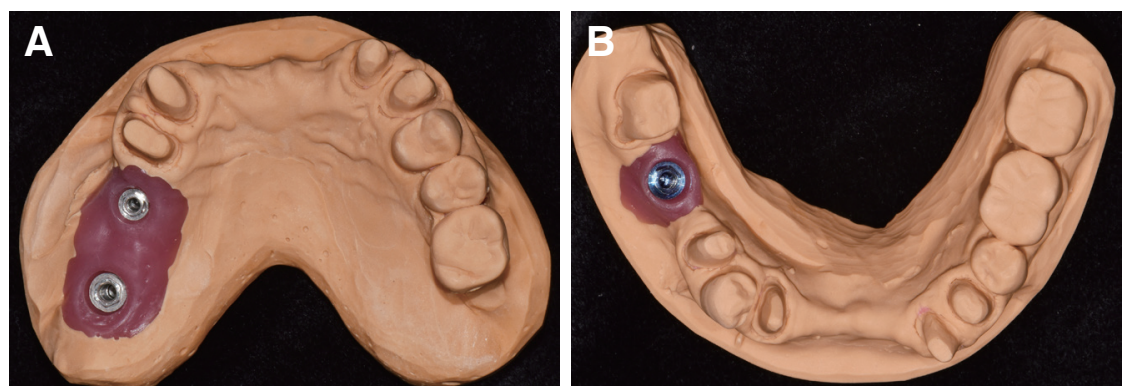

Fig. 7. Master cast fabrication. (A) Maxilla, (B) Mandible.

관리 등을 평가하였고 주기적으로 임시 보철물을 재합착 하여 이차 우식이 발생하는 것을 방지하였다. 이 기간 동 안 환자는 기능적, 심미적으로 특별히 불편함 호소하지 않아 최종 수복 진행하기로 결정하였다.

최종 수복시 자가중합형 아크릴릭 레진(SR Ivolen, Ivoclar Vivadent AG, Schaan, Liechtenstein)으로 개인 트레이 제작하여 폴리에테르(polyether) 인상재(Impregum Grant L DuoSoft \& Penta Soft, 3M ESPE, Minnesota, USA)를 이용해 임플란트의 픽스쳐 레벨 인상 과 지대치의 최종 인상 채득하였고, 주모형을 제작하였 다(Fig. 6, 7). 반조절성 교합기에 임시 수복물 모형의 안 궁 이전 및 화학중합형 아크릴릭 레진(Pattern Resin LS, GC, Illinois, USA)을 이용한 주모형의 교차 부착(cross mounting) 시행하였다. 최종 수복물은 수복물 파절의 위 험성을 줄이기 위해 금 교합면을 가진 금관(gold crown)
과 도재소부금관(porcelain fused-to gold crown, PFG) 으로 정하였고, 임플란트 수복물은 나사유지형(screw type)으로 제작하였다. 최종 수복물 납형 제작 후 되깍기 (cut-back)하여 금 구조물(gold coping) 제작하였고 그 상태에서 환자 구강 내에 시적하여 적합도 및 교합 확인 하였다. 최종 보철물 제작 하여 구강 내 시적한 뒤 교합 조정 후 보철물을 레진 시멘트(RelyX U200,3M ESPE, Neuss, Germany) 이용하여 최종 합착하였고 임플란트 보철물은 제조사의 지시에 따라 $30 \mathrm{Ncm}$ 으로 조였다(Fig. $8,9)$. 최종 보철물 합착 후 환자는 기능적 및 심미적으로 만족하였으며 손 조작능력의 저하와 같은 파킨슨병의 특 성을 고려하여 4 개월 간격의 주기적인 내원을 통해 구강 위생관리를 시행하고 있다. 1 년 간의 관찰 기간 동안 기 능적, 심미적으로 안정적인 예후를 확인할 수 있었다. 

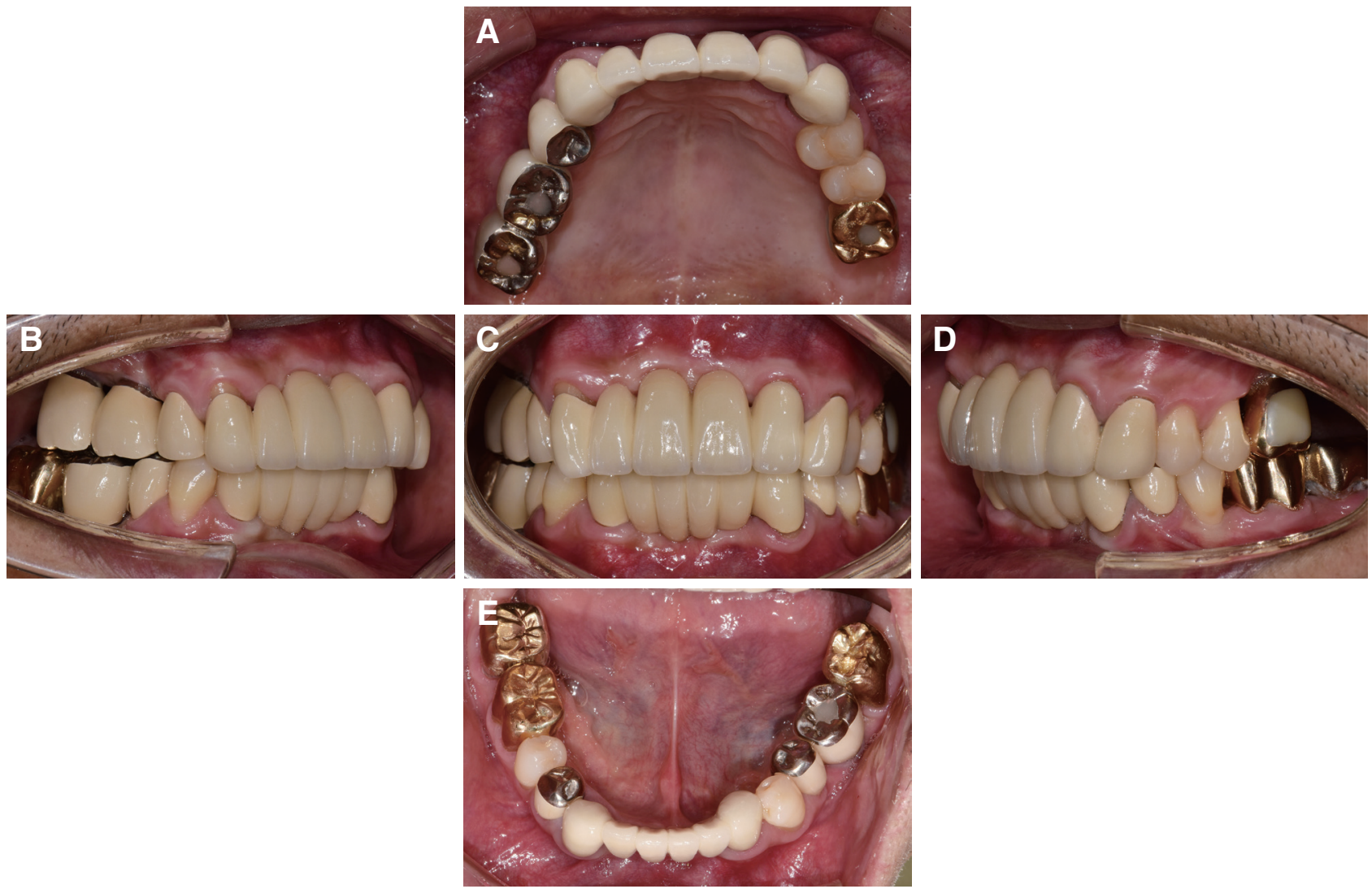

Fig. 8. Placement of the definitive prostheses. (A) Maxillary occlusal view, (B) Right lateral view, (C) Frontal view, (D) Left lateral view, (E) Mandibular occlusal view.

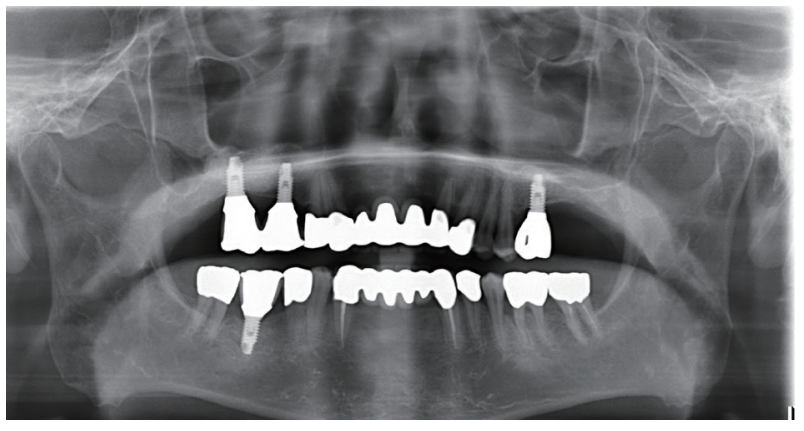

Fig. 9. Panoramic radiograph after placement of the definitive prostheses.

\section{고찰}

파킨슨병은 도파민을 생산하는 뇌세포의 상실로 발생 하는 운동계(motor system) 질환으로 이 질환 때문에 떨 림, 타액의 증가, 근육 조절 능력의 부족 등이 나타난다. 특히 머리의 불수의적인 운동은 치과 치료를 더욱 힘들 게 할 수 있기 때문에 진료를 할 때 특별한 주의를 기울여 야 하며, 인상 채득이나 악간 관계 기록과 같은 보철 수
복의 과정에서 어려움을 겪을 수 있다. ${ }^{5}$

우선 환자의 진료는 최대한 협조적인 시기인 약을 먹은 뒤 1 시간 정도 되는 때 진행되었고 환자에게 진료가 가 능한 상태인지 항상 확인하여 치료시 발생하는 어려움을 줄일 수 있도록 하였다. 파킨슨병 환자의 보철적 진료에 대한 논문에서는 가급적 이른 아침에 진료를 하고 시간 은 45분을 넘기지 말라고 제시하고 있다. 또한 체어를 움 직일 때도 천천히 동작하여 환자에게 기립성 저혈압을 방 지할 수 있도록 해야 하며 각도는 $45^{\circ}$ 정도가 적당하다. ${ }^{1}$ 이에 따라 가급적 진료 시간이 길어지지 않도록 단계를 나누어 진행하였고, 불수의적인 움직임으로 예기치 못하 게 발생할 수 있는 사고를 예방하기 위해 일반적인 진료 에 비해 주의 깊게 치료를 시행하였다.

부분 무치악 부위를 수복하는 방법으로는 크게 가철 성과 고정성으로 나눌 수 있는데 가철성 방법인 부분 의 치의 경우 파킨슨병 환자는 떨림, 안면 근육 경직과 타액 증가로 인해 의치 제작뿐 아니라 의치에 적응하고, 의치 를 유지하는데 많은 어려움이 있다. 심한 파킨슨병 환자 의 경우 의치의 인상 채득시 작업 시간이 짧은 재료를 사 용해야 하며 악간 관계 채득 시에도 적절한 훈련과 많은 
연습이 필요하다. 파킨슨병 환자는 기능적인 하악 운동 을 할 수 없기 때문에 묘기법을 사용할 수 없어서 하악을 중심위로 유도하기 위해 양손유도조작법을 대신 사용할 수 있다. ${ }^{3}$ 고정성 방법으로는 브릿지로 수복하거나 무치 악 부위에 임플란트를 식립하는 것으로, 고정성 보철물 의 경우 마진은 치은연선상(equigingival)이거나 치은연 상(supragingival)이어야 하고 전장관 디자인이 추천된다. 또한 과풍융된 보철물에는 치석이 침착되고 치은의 과증 식을 유발할 수 있으므로 피해야 하고 가공치(pontic)의 디자인은 자정작용(self-cleansing)이 가능한 형태로 제작 되어야 한다. 보철물 접착시에는 미세누출을 피하기 위 해 레진 시멘트를 이용할 것을 추천하고 있다. ${ }^{1}$

파킨슨병 환자에게 국소 마취 후 임플란트를 식립하 는 것은 안전한 과정이며, 임플란트 고정성 보철물은 저 작능력을 향상시켜 환자의 구강 건강뿐 아니라 전반적인 건강에도 바람직한 영향을 끼칠 수 있다. 국소 마취시 에 피네프린은 $0.05 \mathrm{mg}$ 을 넘지 않게 사용하는 것이 안전하 고, 이 수치는 30 분 이내에 1:100,000 에피네프린이 포함 된 2\% 리도카인 카트리지 3 개를 사용하는데 포함된 양 이다. 특히 파킨슨병으로 레보도파(levodopa)나 엔타카 폰(entacapone)을 복용하는 환자의 경우 에피네프린이 포함된 국소 마취는 혈압과 심박수 상승을 유발할 수 있 기 때문에 특히 더 주의를 기울여야 한다. ${ }^{1}$ Pecker는 파킨 슨병 환자 중 기존에 총의치나 부분 의치를 사용하는 환 자에게 오버덴처나 임플란트 지지 고정성 수복을 진행하 여 임플란트의 효용을 평가하였는데 치료 전과 비교하여 치료 후 3 개월, 12 개월의 경과 기간 동안 저작 기능 및 구 강 건강이 전반적으로 개선되는 것을 확인하였고, 파킨 슨병 환자에게 첫번째 치료 옵션으로 임플란트를 고려하 는 것이 좋다고 결론을 내렸다. ${ }^{2}$

본 증례의 환자는 비교적 젊은 연령이었고, 치료에 대 한 의지가 강한 편이었으며, 무치악 부위가 길지 않아 가 철성 보다는 고정성 보철로 수복을 계획하였다. 임플란 트 식립시 다른 환자들에 비해서 수술 과정에 어려움이 존재하였으나 보철물 장착 후 1 년 간의 관찰 기간 동안 특이할만한 합병증은 발생하지 않았다. 파킨슨병 환자의 경우 임플란트의 성공률은 약 $82 \%$ 로 이는 파킨슨병을 가지고 있지 않은 환자에 비해 낮은 수치이다. 수술적 어 려움이 그 원인이고, 정주 진정법(intravenous sedation) 으로도 수술 중 완전히 행동을 통제하기는 힘들다. ${ }^{2}$ 따라 서 임플란트의 정확한 식립이 장기적인 임플란트의 성공 에 영향을 미칠 것이다.
마지막으로 파킨슨병 환자는 손 조작능력을 포함한 운 동 능력이 떨어지기 때문에 구강 위생관리에 대해 특별 한 교육이 필요하고, 환자뿐 아니라 보호자에게도 교육 이 필요하다. ${ }^{4}$ 보철물 장착 후 관리에 대한 교육과 동기 부여가 동반되어야 치료를 성공적으로 유지할 수 있을 것이다.

\section{결론}

파킨슨병은 안면근육에 영향을 줄 뿐 아니라 불수의적 움직임과 같은 행동학적 특성으로 인해 치과 치료를 하 는데 어려움을 준다. 일반적인 치료 과정을 변형하고 주 의 깊게 치료를 시행함으로써 이러한 환자의 부분 무치 악 부위를 전통적인 고정성 보철 및 임플란트 지지 수복 물로 수복하였고, 환자에게 만족스러운 저작활동 및 개 선된 심미를 제공할 수 있었다. 관찰 기간 동안 두드러진 합병증은 관찰되지 않았고, 추후에도 보철물이 장기적으 로 기능할 수 있도록 짧은 간격의 검진을 동반한 구강 위 생 관리가 필요할 것이다.

\section{ORCID}

Eun-Sol Koh http://orcid.org/0000-0001-5259-8911

Joo-Hee Lee http://orcid.org/0000-0002-7907-3098

\section{References}

1. Rajeswari CL. Prosthodontic considerations in Parkinson's disease. PJSR 2010;3:45-7.

2. Packer M, Nikitin V, Coward T, Davis DM, Fiske J. The potential benefits of dental implants on the oral health quality of life of people with Parkinson's disease. Gerodontology 2009;26:11-8.

3. Haralur SB. Clinical strategies for complete denture rehabilitation in a patient with Parkinson disease and reduced neuromuscular control. Case Rep Dent 2015;2015:352878.

4. Al-Omari FA, Al Moaleem MM, Al-Qahtani SS, Al Garni AS, Sadatullah S, Luqman M. Oral rehabilitation of Parkinson's disease patient: a review and case report. Case Rep Dent 2014;2014:432475.

5. Singh Y, Saini M, Garg N. Oral rehabilitation of a Parkinson's patient: A case report. World J Clin Cases 2013;1:67-70. 


\section{만성 치주염을 동반한 파킨슨병 환자의 전악 보철 수복 증례}

고은솔 ${ }^{1}$, 김종진 ${ }^{1}$, 백진 $^{1}$, 차현석 $^{2}$, 이주희 ${ }^{2 *}$

${ }^{1}$ 서울아산병원 치과보철과

${ }^{2}$ 울산대학교 의과대학 서울아산병원 치과보철학교실

파킨슨병은 떨림, 느려진 움직임, 근육의 경직, 자세 불안정성, 보행장애 등의 특징을 나타내는 신경변성 질환으로 도파민 과 같은 신경전달 물질이 고갈되어 생긴다. 이러한 파킨슨병의 특성으로 인해 환자들은 협조적으로 치과 치료를 받는 것 이 어렵다. 본 증례에서는 만성 치주염이 있는 47세의 파킨슨병 환자에게 고정성 보철 및 임플란트 식립을 통한 전악구강 수복을 시행하였고 기능적, 심미적으로 만족할만한 결과를 얻을 수 있었다. 손 조작능력의 저하와 같은 파킨슨병의 특성 을 고려하여 짧은 간격의 주기적인 내원을 통한 관리가 필요할 것이다.

(구강회복응용과학지 2019;35(4):228-34)

주요어: 파킨슨병; 임플란트; 전악구강수복; 만성 치주염 